\title{
NEOLIBERALISM AND CIVIL SOCIETY: SWEDISH EXCEPTIONALISM IN A COMPARATIVE PERSPECTIVE - ON THE CONCEPTUAL AND REAL HISTORY OF CIVIL SOCIETY
}

Sven Eliaeson

Institute for Russian and Eurasian Studies, Uppsala

Polish Institute of Advanced Studies (PIASt), Warsaw

\section{/// Introduction}

Is there a Swedish model of civil society? Probably yes, although it is in demise: there has been a drastic drop in membership for such civic associations as political parties, and other special-interest associations have become increasingly empty shells, raising the question whether they really need their members. Yet Swedes do still have a relatively high degree of participation in various grass roots associations; they are not "bowling alone."

The notion of an exceptional case implies a nomothetic bias - that there is or should be a normal case. This has teleological and metaphysical implications that should rather be avoided. ${ }^{2}$

Moreover, the rhetoric about "exceptionalism" or "Sonderweg" is something we find in many places, for instance, the USA, Japan (S.M.Lipset),

\footnotetext{
${ }^{1}$ Despite some ups and downs the Social Democrats have lost some 100,000 members during the last decade, roughly one-third of their membership. Other associations, such as the Tenants' (Hyresgästföreningen), have become quite corporatist, in the latter case to the extent that they have their counterparts - the real estate owners - distribute their material. In particular the political parties have become a crisis branch and would have difficulties to survive without state subsidies. ${ }^{2}$ It is partly avoided in Stein Rokkan's stages theory, which builds upon the experiences of predominantly north-western European nation states.
} 
and Germany (Veblen, Barkin, Sheehan, Stern, Eley, Plessner, Kocka, etc.). There is no primrose path to modernity, peace, and welfare. However, the variations in political culture seem to be relatively unaffected by political and ideological factors. The future started long ago. In Europe we can already find a handful of different roads to modernity. ${ }^{3}$ Understanding political culture requires a longue durée perspective on history, looking for the future in roots in the distant past. Even if we don't find the independent variable, to use the language of the quantitative method, comparisons are nevertheless meaningful; moreover, it is the method we normally have available in the humanities or social sciences. Since all nations are "dinosaurs" this calls for the longue durée in history and time relativism.

Due to its strategic mixture, Sweden is very useful as a comparative case for studying the role of civil society in political culture in the search for independent variables. Sweden is one of the most Americanised countries in the world, or at least in Europe (the Philippines might be even more so). Yet Sweden's political culture is very different from America's in regards to what the state should do and what things should be financed by public transfers or from individuals' own pockets. Sweden is historically a highly centralised, small, homogenous, and egalitarian, peasant nation, born of taxation - that is, it is pretty much the opposite of the USA in all these respects. ${ }^{4}$

Sweden also displays some exceptional traits that deserve attention in regard to civil society, both concerning its conceptual history as well as its actual history.

In Europe - and one might even say in universal discourse - the old concept of "civil society" re-entered the intellectual scene in the 1980s, following developments in East-Central Europe, originating in Poland. The Solidarity movement was the only truly independent civic association to emerge within the Soviet satellites. It provided an example of civil society as a concept for new social movements that were characterised by civil disobedience against regimes with a deficit of civil rights and democracy and legitimacy. Latin America was also mentioned in the discourse; there

\footnotetext{
3 Peter Flora (1986) is a good example. "Do politics matter?" was a frequent question in political science in the 2000s; evidently the answer is "yes" - but to what extent? For European paths to modernity, see Greenfeld 1993.

${ }^{4}$ Sweden historically, of course, includes Finland, and the two countries are still today in many respects "communicating bowls." The Finns were loyal Swedes and Finland was part of Sweden. In its great-power period, Sweden also included the Baltic provinces and was more multicultural. The relation between Swedes and Finns is complex. Perhaps Erik Lönnroth formulated it best, that in the end - after the Kleinschwedische Lösung 1809 - Sweden and Finland turned out to be two countries built together by two people.
} 
were several examples of corrupt regimes with low popular legitimacy where some monitoring of the government was provided by new networks, and "civil society" was used as an old and revitalised label. Civil society might be rather impotent as an analytic or taxonomical concept, but it has certainly proved useful for generating debates about what makes a society hang together and tick.

\section{/// Four Modalities of "Civil Society"}

The conceptual history of civil society is complex and could take its point of departure anywhere between Aristotle and Hobbes (or Samuel Pufendorf, who represents the diffusion of Hobbesianism), or from the "republican" parts of Machiavelli's oeuvre. Today we have a sudden oversupply of new or reborn concepts, such as globalisation, risk society, glocalisation, postmodernity, mixophobia, and so forth - not to forget civil society. Only some of these concepts will survive. Other concepts, such as "class" and "nation" are still going strong but need monitoring for their cognitive relevance, which might vary considerably. In well-consolidated north-western European welfare states they have become increasingly less relevant since the Second World War. ${ }^{5}$

Four main clusters of civil society types can be identified. One is the Scottish type, which was engendered by the Scottish Enlightenment and in which civil society is synonymous with bourgeois society, commercial society, or sometimes with "polished" (civilised) society, in contrast to previous stages of human development, such as those centring on gathering, hunting, herding, or agriculture. The market and private property are the core. Evidently there is a lot to it, from a historical point of view, while previous Hobbesian approaches have been restricted to rational reconstructions, explaining why the individual has to adjust to peaceful coexistence in a legitimate order. From Ferguson on, this variation has been the classical one, which also dominates in neoliberal usage.

It is a puzzle, in the history of ideas, why no breakthrough to Enlightenment social science occurred in France at the same time, especially since there are links between, for example, Turgot and Adam Smith, and there are many embryonic elements in the works of Montesquieu that would

\footnotetext{
${ }^{5}$ Not fully irrelevant - perhaps "dismantled" is a better characterisation. Thinkers such as Richard Rorty stress the need most common people still feel for a natural identification with a nation state, even in the age of globalisation and Europeanisation. The same point was made by Chancellor Helmut Schmidt (for instance, in Die Zeit, 22 April 2004).

${ }^{6}$ Ferguson often used this term.
} 
have made a French breakthrough rather natural. Instead, the Scottish Enlightenment and the various four-stages theories brought us both civil society and sociology. Since Saint-Simon and Comte continued the French tradition, one possible explanation could be the inhibiting effects of Rousseau's Romantic, anti-Enlightenment confusions and contradictions (Eriksson 1988).

There is evidently a high correlation between the state, the market, and civil associations promoting democracy - or at least a constitutional order (Rechtsstaat). It is a paradox that the anonymous mechanism of the market stimulates both (limited) state power and generates a considerable amount of human interaction, both in trade (which is less surprising) and in clubs of various sorts, just as de Tocqueville, and later Max Weber, noticed during their American travels (Offe 2004). It appears that all democratic states employ the market system, but there are evidently also market systems without democracy. In one way the market appears to be a threat to democracy, since decisions are made outside the representative, democratic decision-making polity. Yet the market provides a basis for the revolt of the masses against the elites, in terms of free choice - in regard to nutrition, for instance, or the many allocation decisions about goods, where centralised decisions simply tend to be clumsy and dysfunctional. ${ }^{7}$

Second, we can recognise a Hegelian type, in which the state has a certain primacy, with a focus on civil society as a conglomerate of civic associations forming the state. We avoid the "iceberg" of scrutinising the Hegelian case more closely, except for noting that independent of what distinctions Hegel makes between the state and civil society, there is a strong state-idealist bias in his approach, which is less intrinsically interesting to us, although, of course, it is a nice example of the seminal contextual element in conceptual history, since state idealism has more fertile soil in nations without states or in strong states with undefined nations. It is not by chance that liberal doctrines develop in countries with a relatively wellestablished state power and calculability in the legal system (although we have the so-called problem of England here - and to some extent also the problem of the USA - in regard to the legal framework, which deviates from systematic Roman law).

Third, there is what I call a "Polish" type, meaning civil disobedience and protest movements against regimes with low legitimacy. This definition was embraced by a number of American sociologists travelling east

\footnotetext{
${ }^{7}$ I would like to mention Charles Lindblom's work (1977) as a particularly nuanced account, in a field full of ideological believers.
} 
of the Elbe in the wake of 1989 (for instance, Jeff Alexander and Rogers Brubaker), but it was also cultivated by local scholars. ${ }^{8}$ During the long partition the Catholic Church substituted for a missing real society. The role of the family is hard to understand for a Swede, who has grown up with state-sponsored individualism.

Fourth, we can speak of a "Graeco-Roman" republican or communitarian or perhaps Habermasian-conservative variation, with a focus on local self-determination. Alan Wolfe (1989) is one prominent exponent of this approach, synthesising Graeco-Roman elements with Habermas's ideas about the need for Lebenswelt regaining ground from a suffocating Systemwelt. There is a human need for a sphere of self-control, to get central government off one's back.

If I see somebody at an airport gate reading, for instance, Plato or Aristotle, I can be rather sure the person is American. In the US constitutional order, the link with the classics of antiquity is alive and visible, a heritage carried over the Atlantic via Switzerland. Swiss scholars contributed to California's constitution, which appears to be an exaggerated version of the US constitution, with lots of local referendums, and so forth. In Machiavelli's Florence, moreover, the Florentines did not think they lived in the Renaissance but thought of their city as a recent "Greek" city state.

Despite the fact that both Hegel and Habermas are pretty much "dead dogs" in Swedish discourse, the Swedish case of "real" civil society (civil society avant la lettre) nevertheless unites traits from both the Hegelian, Scottish, and Habermasian/conservative/Graeco-Roman modalities, while the Polish type is almost absent and the Scottish one rather neglected, despite its central role in intellectual history. ${ }^{9}$ In Sweden, uncontrolled but trusted expertise tells the citizens what is good for them, for instance, to "eat six to eight slices of bread every day," and so forth. There is a perhaps naive trust in state agencies as being well intended and at the citizens' service.

\footnotetext{
${ }^{8}$ For instance, Geremek 1991.

9 This is a judgment with some anomalies that have to be explained ad hoc. For instance, religious non-conformists in the mid-nineteenth century fall outside the general pattern but are very momentous for cultivating more inner-worldly associations and interest groups, thus unintentionally paving the way for modern mass democracy. Yet they also illustrate the typical Swedish merger between a top-down and bottom-up perspective; being a practising sect member and a state church member simultaneously was more the rule than the exception in Sweden. This had to do with Swedish law. It used to be illegal not to be a member of the state church. The early Age of Liberty was not very liberal in terms of freedom of thought, especially not dissenting religious ideas, a legacy from Arvid Horn's days in power.
} 
The classical Scottish modality of civil society also makes us face problems that remain unresolved with the concept of civil society. Doesn't the market have an inhuman, deforming, and corrupting influence on us as human beings $?^{10}$ Civil society combines self-determination with utopianism, which might appear to be squaring the circle.

\section{/// Civil Society in Sweden}

In Sweden, in contrast to the countries of East-Central Europe, the concept of civil society entered the scene about a quarter of a century ago, as part of a neoliberal and social-conservative reaction against social-democratic rhetoric about the strong society, or the strong state, as supportive of the weak individual. The very lack of a distinction between the state and society in Swedish consciousness was one point of departure for this antisocialist offensive. ${ }^{11}$ There are paradoxes involved. If the general picture is that scholars in the USA and Europe have tried to re-conquer the concept from the neoliberals, in Sweden the neoliberals won by walkover. The concept of civil society was shaped by the anti-socialists as indicating a mediating sphere between the state and the "small context" of interpersonal ties, be it households or individuals interacting in clubs, civil associations, or parishes. As such, the concept remained uncontested. "Less state, more civil society" could be a slogan for this reaction against centralised state power and excesses in rapid large-scale solutions, which have already been criticised by Gunnar Myrdal (1982). ${ }^{12}$

There is a certain resemblance between the way the "right" (whatever that concept today is supposed to denote) managed to hegemonise the concept of civil society and the way the social democratic leader Per Albin Hansson in the late 1920s managed to take over the concept of Folkhemmet

\footnotetext{
${ }^{10}$ Erich Fromm and Robert Lane might have some problems with intersubjectivity, and there is a risk that non-testable clichés or "interpretative schemes" will replace theories. Yet they are telling and have "value added" for our understanding of modern market society. "Shop until you drop" syndrome; manipulated "market-soldiers" who instead of consuming real life, substitute pseudoexperiences, such as watching reality TV shows, becoming soccer-hooligans, attending so-called bingo-lotteries, etc. Social psychological research is called for, to follow up on Fromm, among others.

${ }_{11}$ There is a distinction in the Swedish language between stat and sambälle - but the words are often understood by the ordinary Swede as synonymous.

${ }^{12}$ In his case this must be seen as a self-criticism - highly relevant but little noticed. In the 1930s Myrdal was a great social engineer in the Saint-Simonian, "Jacobinian" non-liberal tradition. As Sweden's "grumpy old man" he made a reckoning with his own creation, probably without being aware of the boomerang effect.
} 
(the people's home, Volksheim/Volksgemeinschaft), which was launched by the social conservative Rudolf Kjellén. ${ }^{13}$

Anti-socialist is a better term than neoliberal, since one of the many paradoxes in recent Swedish conceptual history is the unholy marriage between neoliberals and conservatives. For some time, the problem nexus "less market, more civil society" remained a tacit dimension, a neglected complication (that is, that both the state and the market could damage civil society). The leading and bridge-building role of the Swedish-American sociologist Hans Zetterberg provides one possible explanation. Zetterberg emphasised the small-scale context and compassionate dimension of love and personal concern. The state, according to Zetterberg (1995), is more of a machine, to which no personal ties of responsibility or accountability really apply, while the family or parish somehow promotes reciprocity and solidarity, which has been lost during the growth of the top-heavy public sector. ${ }^{14}$ It is also easier to cheat the system than your neighbours. Der innere Wächter or the internalised "Martin Luther" needs some help from social control, which calls for a smaller context and less anonymity, to check that you are not "cultivating your garden" when you are supposed to be in bed with a fever. It is an odd fact that the Swedes are simultaneously the healthiest and sickest people in Europe, depending on which statistics one consults - insurance data or social-medical indicators (life expectancy, child mortality, etc.).

However, the successful hijacking of the concept by no means meant that the neoliberals and/or antisocialists won the debate (as such) about the proper balance between the state, the market, and (civil) society. At least on the scholarly level this discussion - about the design of the welfare state and its institutions, and the principles of (re)distribution - employed the

\footnotetext{
${ }^{13}$ Kjellén is sometimes characterised as a proto-fascist, although his term "national socialism" is accidental. He is most known for geopolitics and his scholarly relevance is perhaps due to his early brand of resource analysis in international politics. He was a main source of inspiration for Gunnar Myrdal, especially Asian Drama. Kjellén, however, was not the first to use the concept of Folkhem, whose provenance is unclear. Norbert Götz (2001) has traced the term to Denmark in the 1860s. ${ }^{14}$ One example is "Kindergulag in Schweden" in Der Spiegel, an article by Herman Orth, documenting how taking children away from unfit parents is many times more frequent in Sweden than in any comparable country. This might be humane - yet it is problematic from the viewpoint of human rights (Rechtsstaat) and integrity. Certainly many cases are well motivated (suburban "latchkey kids," perhaps with drug-abusing mothers, etc.) but if this is many times more frequent in Sweden than in comparable countries it appears alarming, especially as the officials making the decisions have little legal training and the need for the "service" is decided by the service providers, a problem common to some public sector activities, especially in health care.
} 
famous "Titmussian triad" (Titmuss 1962), or its more ideologically coloured "regime" re-conceptualisation by Gösta Esping-Andersen. ${ }^{15}$

It would be an exaggeration to suggest that Sweden has been unaffected by the general neoliberal wave. The market mechanism came into use as an indicator, albeit fictive, in public services, and privatisation in various forms became fashionable and was increasingly also practised in the form of "contracting out," franchising, and so forth. Hospital patients became "customers" or "clients." This was more noise than deeds and also had other reasons, such as a Machiavellian decentralisation of decision-making in times of scarcity and cost elimination. The decrease in state-level relevance is illustrated by the fact that many topics on the national political agenda at election times were really about decisions that had to be made on the local or regional level, due to how the social state is organised in Sweden, with local government taxation financing education, health care, and so forth.

Neoliberalism is alien to Swedish political culture, even if a couple of decades ago the social democrats were influenced by fancy, predominantly neoliberal, yuppie culture to initiate a certain flirtation with this group in the electorate. The weak basis for neoliberalism is further indicated by the aftermath of the neoliberal wave, which in Sweden seemed to result in an increased interest in the communitarian alternative, as a pragmatic synthesis. This is furthermore indicated by the renaissance of traits common to socialism and conservatism. A re-evaluation of Rudolf Kjellén is part of the trend. So is the interesting fact that the main combatants in defending or attacking the large public sector have displayed, independently of each other, a certain positive curiosity about communitarian strands of thought. They might have very condescending things to say about each other, but they are clearly more cautious in what they claim about Robert Putnam, Etzioni, or Sandel, for instance. It might be said that there was a convergence once the heated ideological confrontation had peaked. It might also be added that communitarian notions about Lokalvernuft as a pragmatic solution to the value-incommensurability, "polytheist" problem in the postEnlightenment harmonises well with the tradition of Scandinavian legal realism, with the legal positivists following in the wake of the so-called Uppsala school of value nihilism, and with Axel Hägerström as prophet and Gunnar Myrdal, Alf Ross, and Karl Olivecrona as (some of) the apostles.

${ }^{15}$ Sven E. Olson (later Olson-Hort, and later than that, Hort) is a good example. See also EspingAndersen (1990). 
Sweden, again, provides a case of "real, existing civil society" avant la lettre. What is quite typical of the Swedish case is private local initiatives seeking state support - and getting it. This is the way Sweden became electrified, the way savings and loan banks were created, and the way early insurance systems emerged. These were initiatives for modernisation from below, from the bottom-up, but soon growing into the state apparatus, with its surveillance and top-down perspective. This merger between topdown and bottom-up is perhaps not exclusive to Sweden, but it is a typical trait. ${ }^{16}$ Local government, being simply in need of people to fill all the necessary functions, desired citizens with a creed of citizenship. ${ }^{17} \mathrm{~A}$ high level of literacy, even long before the school reform decision of $1842,{ }^{18}$ and the immense role of people's mobilisation and participation in various popular movements, created a political culture of active responsibility and accountability. This political culture managed to accommodate a strong central bureaucracy, which survived a number of radical constitutional shifts, and represented continuity. ${ }^{19}$

\section{/// The Intimacy of the Rulers and the Ruled in Swedish History}

The roots and reasons for the farmers' (sense of) participation are to be found in Swedish history, going back even to medieval times, as indicated by research by Eva Österberg and others. The peasants in Sweden felt they had a stake in the running of the government - and to some extent they did. The landowning and tax-paying peasantry formed a recognised po-

\footnotetext{
${ }^{16}$ There are a number of civic-culture organisations between the private and public spheres. These are often so-called promoting associations (främjandesällskap); they take off as private initiatives but later become part of the bureaucracy. See also Stephen Turner (2006) about Swedish-type civil society.

17 This has changed, due to local government reforms and rationalisation, in two waves, in 1952 and in the 1960s (a decision taken in 1962), reducing the number of local governments from around 2,500 to below 300 . Whether the middle level of landsting (county council) should remain or not is a recurrent issue; today much of health care is handled by the landsting.

${ }^{18}$ In 1711 no less than $58 \%$ of the soldiers in Elfsborg regiment could read and exactly one hundred years later $99 \%$ could read; today the percentage is probably higher. The corresponding numbers for the ability to write readable texts were $5 \%$ and $18 \%$ respectively (according to an email from Jan Lindegren of 1 June 2004).

19 Axel Oxenstierna is in several ways the pivotal historical figure in building a central state bureaucracy that managed to accommodate a number of regimes, including the social democratic one in the twentieth century, and in making individuals attached to central government. Oxenstierna also promoted the careers of commoners, often the sons of peasant students with whom he had become acquainted as a young student in Germany. They launched into careers in the priesthood. During the Era of Liberty, further formative steps were taken towards the creation of independent and impartial Swedish state agencies. Charles XI broke the power of the high nobility - but also created a new "domesticated" civil-servant nobility.
} 
litical force very early. Between one-third and half of the land was in the hands of "self-owning," tax-paying peasants (although the legal regulations for title to land varied somewhat; the issue has a complicated history and was at times a matter of conflict).

The word for peasant in the Swedish language (bonde) has no genuine correspondent in other languages. It has positive connotations of pride and self-reliance which are not found in other languages, where words such as "villain," "peasant," "farmer," "Bauer," and so forth, often have a slight whiff of condescension about them. Something very important here gets lost in translation. The Swedish peasants also had a long tradition of local self-determination and "freedom." Swedish peasants were never fully feudalised. There is also a mythical tie between the king and the people, reflected in the right of the citizens to "write to the king." The king was seen as the "First Peasant." It is less important if these images about local self-determination and peasant power were myth or reality. To a large extent they are an invented tradition of nineteenth-century patriotic national "liberal" history-writing with its recurrent criticism of the nobility. This live myth was a useful fiction. The high nobility might have been powerful during the Great Power period (mainly the seventeenth century), especially during the reign of Queen Christina, but had "bad press" in Sweden, especially in nineteenth-century history-writing.

In actuality, Gustaf Vasa (reigning 1523-1560, Sweden's Kemal Atatürk or Józef Piłsudski) had to depend on the nobility in his power-balance act. His grandson Gustavus Adolphus even had to make major concessions to the higher nobility in order to secure his throne. This, however, does not really alter the dominant stereotype of the king and people keeping the nobility on a "short leash." As demonstrated in Eva Österberg's research (e.g., 1991) the mental structure of the late medieval peasant village with its combination of solidaristic egalitarianism and envy is an embryo for the design of the twentieth-century welfare state.

Sweden is one of the few places in Europe where the peasants actually won during the many uprisings in late medieval days. This happened also in Dithmarschen (a part of Schleswig-Holstein) and Switzerland. While Wilhelm Tell is mythical, Sweden was indeed ruled by Engelbrekt Engelbrektsson for about two years (1434-1436) after he led a rebellion backed by farmers and miners against King Erik. Engelbrektsson was assassinated by a nobleman and became a martyr. ${ }^{20}$ In Swedish state-formation - as

${ }^{20}$ Engelbrekt as a man of liberty is a retrospectively invented story, yet his role in history is quite remarkable. However, it is a matter of interpretation. Lübeck owned shares in Falu copper mine 
reflected in Swedish educational indoctrination - Gustaf Vasa's adventures in Dalecarlia loom larger than his later brutal assaults to punish grass roots reactions against his methods of taxing the peasantry. Peder Svart's chronicle is not exactly unbiased, yet it is live memory still today. Until recently, every Swedish school pupil had heard of Gustaf's adventures in Dalecarlia and how the peasants from Mora finally offered their support for his insurgency against the (Danish-)Union king, Christian "The Tyrant," as he was sometimes called in Sweden. Peder Svart's narrative might be propaganda; the fact is that still today, on the first Sunday in March of every year some 15,000 cross-country skiers compete between Sälen and Mora. Gustaf Vasa was going in the other direction, trying to escape to Lübeck, when the peasants caught up with him and said they had changed their minds; now they wished to join the rebellion against the Danish-dominated Nordic Union (the Kalmar Union between 1397 and 1523).

Swedish political culture is today still much imprinted by Gustaf Vasa and also by Axel Oxenstierna (chancellor 1612-1654), who promoted - far more than most Swedes are aware - the idea of impartial state officials. They are the source of one of the main characteristics of the Swedish welfare state and its public sector: a relativel ${ }^{21}$ high propensity to pay taxes, even if with a certain masochistic chill, combined with a trust in institutions.

There are other factors that deserve mentioning. One specific circumstance was that sons of peasants could study and become priests, which produced a sort of "intimacy" or partnership between the rulers and the ruled. The priests were the voice of the central power, and not that rarely the priest was also "one of us." The priest's residence was the local power centre and the priest normally chaired meetings of the local government council. In addition, the priests were sometimes themselves literally peasants, since part of their salary involved a homestead, which they could either cultivate themselves or lease to a tenant. They were additionally also public servants in their capacity of priests, and not infrequently priests'

(Stora Kopparbergs Bergslag, today StoraEnso) and the iron mine in Norberg, very close to where Engelbrekt came from. Evidently the Hanseatic League and the small-scale iron producers in Bergslagen had common economic interests, which conflicted with the Nordic Union. This has been pointed out by Erik Lönnroth (1934).

${ }_{21}$ This characterisation of Gustaf Vasa might be a stereotype. After all, the Reformation was a widespread phenomenon. What happened in Sweden (including Finland, of course) was not unique and not extreme. Closing down Uppsala University, which was a Catholic stronghold, appears in a different light from this perspective, although Gustaf Vasa could have re-opened it as a Protestant institution, which happened two generations later. 
sons became high state officials. Thus there was a ladder for class circulation: from peasant, to priest, to Beamter (state official). ${ }^{22}$

In addition to the free-peasant mythology, there is another tradition that contributes to the negotiated order and atmosphere of consensus, but more from the top-down perspective, that is, the tradition of "feudal capitalism," especially in the iron industry, before it became large scale. The word bruk is another of those terms having very typical denotations and connotations that simply get lost in translation. The literal and "flat" translation could be "plant" or "factory," but bruk also means a place where the owner-family and workers live in a sort of community, generation after generation. It is not market capitalism, since the owner has a responsibility for the welfare of his community; there is no "outsourcing" on the decision agenda. ${ }^{23}$ The existence of this type of community is not specific to Sweden; we need only mention the Fuggerei in Augsburg, and Marienthal, south of Vienna (today part of Graumatneusiedl). Henry Ford's family housing at his car factories is also a parallel. But the bruk is part of the background of Sweden's climate of consensus and class compromise.

The cooperative network economy that was cultivated in the bruk-ambience is worth more research to elucidate how the transformation into the modern Swedish welfare Folkhem took place. ${ }^{24}$ This is an important piece in the puzzle.

Swedish social engineering has thus been historically well prepared for its strange merger between top-down and bottom-up. The long background of the peasants' (feeling of) having a stake in the running of the state, as an integrated political force, is also the reason for a certain blind-

\footnotetext{
${ }^{22}$ Sten Carlsson - a leading Uppsala historian with a background in Lund - makes this point in his works on Swedish social history. Although the last, rather formal, privileges of the Swedish nobility have lasted into the third millennium, the nobility never had an efficient monopoly on high offices. (The most famous example of class circulation is Johan Skytte, who was the son of a bourgeois and who re-established Uppsala University after its demise under Gustaf Vasa and his sons. He also, together with Salvius and Grotius, negotiated the Treaty of Westphalia on behalf of Sweden.) In this context, we should also mention that we had a state church in Sweden until 2000.

${ }^{23}$ A good example is Lesjöfors bruk, where Baron de Geer has to pretend that he likes "bandy," a strange variation of ice hockey but with a smaller ball and played outdoors, sometimes at $20{ }^{\circ} \mathrm{C}$ below freezing point. The spirit of the bruk is rather egalitarian (among the workers; it is also a stable, class society) and somewhat "thick" or "ingrown" - not that different from a medieval village, with its typical combination of solidarity and envy. Fairly large communities might have a live bruk tradition. This goes for Bofors, where howitzers are made. No one sticks out in this (very un-American) ambience. This is where the famous "law of Jante" rules (Bernd Henningsen has written on this, and Aksel Sandemose gave us the concept).

${ }^{24}$ There are some relevant studies, for instance, Ylva Hasselberg 1998.
} 
ness to the "free-rider" problem in modern welfare states and for trust in institutions (which is more of a deficit in most comparable countries). ${ }^{25}$

One of Zetterberg's main observations was that Swedish social insurance is very individualistic - meaning that it enables, for instance, single mothers to enter or remain in the workforce, to exit ingrown paternalistic family contexts, and to recast their lives and achieve "self-realisation."

\section{/// The Swedish Case in Comparison}

The contrasts are clear between the peasant legacy in Sweden, and countries such as Poland, where the history of self-determination in modern times is fairly short, or Russia, where the full-scale Soviet experiment in expert rule was quite hostile to spontaneous civil society manifestations, which, moreover, had a poor seedbed in the lethargy deriving from semstvoand mir-traditions.

It has actually even been suggested that the self-owning peasants in Sweden had in effect as many political rights as the poorer nobility in Poland, although the szlachta zagrodowa shared a value system with the high nobility (David Kirby 1995[1990]). This might be an exaggeration - but a telling one.

There are reasons to be on the alert against teleological and apologetic interpretations of the Swedish case. Any account of roots might invite "whiggish" interpretations, especially since the Swedish system has been very successful in many ways, with the Social Democrats as the "Whigs." But there is no determinism involved. There are many alternatives in history. The above account only indicates that the development that actually did result was deeply embedded in long historical traditions. It remains nevertheless a historical question why the Swedish way has differed so much from the Swiss way. Both countries had many similar historical conditions, including the religious factor and a nature that made feudalisation a difficult project. Both countries have been rather successful, but with different polity designs.

\footnotetext{
${ }_{25}$ There is a great deal of literature on the subject, such as the recent contributions by Bo Rothstein on trust, which is also the topic and title of a whole book by Fukuyama. Ten wallets with money and no owner's address were dropped in the street in various cities. In Oslo, ten were turned in to the police; in Stockholm, seven, in Istanbul zero. This does not mean that Turkish citizens are more criminal than Norwegians; rather they feel no trust in their police institutions, so it would be pointless to hand the money over to the police. I have had similar experiences in Poland, where I lived in the years 2002-2007 and where I regularly visit.
} 
The long-term traditions also indicate why Sweden is hardly a model to copy. To a liberal, moreover, the Swedish case must appear as a dystopia, with its authoritarian and top-down traits, which have been made even more pronounced by the Lutheran social reform creed, with its almost totalising Saint-Simonian Enlightenment reason. The Myrdals' social engineering provides good examples of this. Roland Huntford's book on "the blind totalitarians" might be much exaggerated but has a kernel of truth, in the sense that Swedes seemingly are happily unaware of the dangers of Rousseauian "populism," or that democracy has a totalitarian element and is to some extent opposed to liberty. One might say that Sweden, even formalised in the constitution of the 1970s, is too much a ("monistic") democracy but is hardly a full-fledged Rechtsstaat. The Swedish constitution would be totally unfit for, let's say, Belgium, Germany, or Bosnia. There is, furthermore, no tradition of law review in Sweden and the judiciary is not independent but is considered part of the administration (which is, it must be added, fully independent of the government cabinet). Minority rights and even individual rights are not as strong as in more liberal and less democratic systems, for instance, the constitutional order of the USA, where legitimacy rests on the individual and John Locke is still going strong. ${ }^{26}$ Furthermore, there is no constitutional court, since it would violate the sovereignty of the people in parliament assembled. But we do have a deeply rooted culture of laymen in the court system. That Sweden is - historically - a small and homogeneous peasant-state, with a lot of solidarity - and envy - is the main source for the specificities of the Swedish modality of civil society. Today Sweden is, of course, rather multicultural, but a hundred years ago it was as homogenous as Poland is today (about $98 \%$ of the population was of the "ethnic" majority stock; I put "ethnic" in quotation marks, since the provenance of the term is somewhat opaque).

Regional cleavages are normally not capitalised in politics, despite the fact that there are some such gulfs, although certainly much less than in regional and federal Germany. One has only to look at the electoral map of recent EU-referenda to realise that there is a gulf between the backward northern territories, the large city regions, and the Europe-oriented south. Sweden might indeed be historically - mainly - a small, centralised, homogeneous, peasant country, ${ }^{27}$ but there is the partly Finnish-speaking

\footnotetext{
${ }^{26}$ The role of Hägerström and Lundstedt and so-called Scandinavian legal realism must be mentioned and can hardly be overestimated. I don't elaborate on this very intriguing theme here. See Eliaeson (2000, 2006a, 2006b).

${ }^{27}$ Recent multiculturalism might make this a suspect statement, bringing to mind the racist bedmates of communitarianism, as Zygmunt Bauman formulated it. Today's Sweden is multicultural - rather
} 
Tornedalen up north, and greater Scania, including the lands of Blekinge and Halland, with their own identities and centrifugal powers. ${ }^{28}$ The same is true of lands such as Dalecarlia (Dalarna) and Värmland. In general, though, local patriotism is not much of a factor in political life, where electoral geography plays little role. There is no serious separatism anywhere. Stein Rokkan is very sensitive to cleavages but notices that Sweden lacks any major ones.

An almost amusing example of the tacit corporatism in the small and homogeneous peasant state and the merger between top-down and bottom-up is that the representation of the Sami people (Sametinget) is also in fact part of the Swedish state administration (see Vasara-Hammare 2002), and to some extent functions as a state agency, despite extremely important lawsuits between the Swedish crown and the Sami people about who really owns the mountains up north, including many iron-ore-rich areas. Independently of what the court decisions may be, it can safely be predicted that the original Sami owners will not take over the iron-ore fields in Lapelonia (Lapland). A consensual solution "the Swedish way" is anticipated. ${ }^{29}$

Another corporatist-promoting peculiarity (shared with several continental powers, but distinguishing us from the Anglo-Saxon tradition) is that civil servants are eligible to run for public office and, for instance, get elected to parliament, where they can decide on money for their own special interests. The notion that they are sitting on two chairs and have a self-interest in budget decisions and so forth is lacking. This is part of the Swedish climate of consensus, in which responsibility may be taken on various levels. ${ }^{30}$ In Sweden, there is an unnoticed risk that public tax money

than integrationist - and has an immigrant population of about $15 \%$ of the population as a whole. However, in Swedish statistics, one foreign-born parent is enough to cause a person to be classified as of immigrant background - and of the immigrants the Finnish part is about half of the group as a whole. After 700 years of common history it seems slightly odd not to take this into account. The point with the homogeneous and egalitarian peasant population is that Sweden has never been at the crossroads of people coming through before finding their homelands, in contrast, for instance, to northern Italy or Ukraine, where countless new waves have left their imprints. Sweden has never been occupied by foreign forces, if we keep in mind that we entered the Nordic Union voluntarily. The Nordic Union did not really become a "starter," basically due to communication difficulties, but was in principle in force during the fifteenth century, until Gustaf Vasa conquered Stockholm on Midsummer 1523.

${ }^{28}$ Finnish history before 1809 is identical with Swedish history and Scania's (Schonen's) history before 1658 is identical with Danish history. But the history curriculum is the same throughout Sweden. Finnish websites might be a good source for learning about Swedish history.

${ }^{29}$ In Sweden any mining company can make a claim to exploit ore resources on land belonging to any private owner. So owning land in Sweden means owning the surface soil, to about a meter deep.

${ }^{30}$ Gunnar Myrdal (1982) makes quite a point of this. 
may become a Selbstbedinungsladen, as the German expression goes - a selfservice shop.

To a pure-hearted socialist, Sweden must appear to be a strange hybrid (a middle way, a "third way"), since the revisionist class compromise has resulted in a system with socialised consumption and monopoly capitalism in good consensual cooperation, with a high degree of involvement of organised interests: first the blue-collar workers, followed by the white-collar workers.

Yet another illustration of Swedish corporatism is Folkets bus (see Kohn 2003), where sometimes the formal power even becomes a tenant of the people's movements, when the local government council has its headquarter in Folkets bus.

To the communitarians the Greek city state, Swiss canton, or US local government traditions apply better; here Sweden rather provides fertile soil for missionary endeavours, due to the stalemate between liberals and socialists in the civil society controversy. But Swedish traditions imply ready soil.

That the Swedish system nevertheless enjoys high legitimacy and consent is due to long traditions promoting participation and trust in institutions. The relations between civil "promoting associations" and institutions require further empirical and historical research. On a theoretical and heuristic level, game theory and Mancur Olson's thinking about collective versus individual rationality might be helpful. Rational choice plus history is a nice combination, which we find already in Max Weber's critical scrutiny of Eduard Meyer (Tenbruck 1987; Weber 1906). Solidarity and democracy can hardly be deduced from the viewpoint of individual rationality. Yet they exist and are increasingly popular, in the worldwide perspective.

In the Polish case, in contrast, the Solidarity movement as a conglomerate of interest groups was successful in articulating discontent with a dysfunctional and corrupt system - but apparently it was not ideally designed for the furtherance of common goals and values (Gemeinwohl). In that regard it is even dysfunctional. To unite against something is much easier than for something. As a social movement Solidarity in Poland was the success of the twentieth century.

One root of modern Sweden that deserves mentioning - although we won't delve into the topic - is the parliamentary experience in the Era of Liberty (see Metcalf 1987; Roberts 1986). It is remarkable that Sweden actually already had a (sort of) parliamentarian rule in the eighteenth century, with parties in parliament - especially considering that the breakthrough 
to modern mass democracy and equal suffrage was late - half a century later than, for instance, in Prussia. A cynical observer might, of course, claim that this proto-parliamentarianism - just like in the British case was really a system of bribery and that power holders bought support from members of parliament (this being the origin of party groups and the parliamentarian system). Towards the end of the period it was actual parliamentarianism, and shifts in power were no longer motivated in judicial terms. ${ }^{31}$

There is little constitutional debate, or much serious security-policy debate, as issues on the political agenda. ${ }^{32}$ Security policy has, however, re-entered the agenda after Russia's annexation of the Crimean peninsula. The main parties are not in conflict over the basic lines but over the details of financing, and so forth, and the more precise nature of our relation to NATO. Today, it is documented that Sweden has been a "secret member" since the early 1950s.

Some "community of assumptions" - not only over the rules of the power game but also concerning belonging and community - supposedly promotes cohesiveness and civility. There might be a certain frustration over a lost sense of identity in Sweden, although this should not be exaggerated. Belonging somehow implies exclusion, just as Carl Schmitt said, ${ }^{33}$ and Sweden is after all a country without deep cleavages. On the other hand, a community without a purpose or common goal might start to erode and disintegrate. Again, a sense of proportion suggests that we should not exaggerate this threat; talk about "atomisation" and the dissolution of natural bonds in "industrial society" has been going on for two centuries and even very rootless societies, such as California, seemingly hang together.

It is easier to preserve national unity and social peace in a consensusoriented homogeneous state, compared to, let's say, India or Canada. Swe-

\footnotetext{
${ }^{31}$ Jan Lindegren points out that the Swedish constitution of 1721 was very momentous and the text was taken seriously in the American way (instead of the later focus on constitutional praxis). The processes of modernising the forms of the state and political exchange were parallel in Sweden and the UK - but the "Modernists" won in Sweden and remained in opposition in the UK, although Sweden then experienced a royal counter-revolution in 1772. Lindegren even suggests (in an email from 1 June 2004) that it might even be suggested that a parliamentary initiated revolution was imminent in Sweden a quarter of a century before one took place in France. This provides food for thought given that the development of modern mass democracy, as a contrast, was very late in Sweden).

32 There is scholarly debate, though: for instance, Olof Petersson's pioneering work in matters of citizenship and the public sphere (the SNS's "Constitutional project"), and Bo Huldt and his collaborators at the Swedish "Försvarshögskolan" (Defence Academy), trying to realign Swedish foreign policy doctrine in the wake of die Wende.

${ }^{33}$ Carl Schmitt claims that friend and foe are the basic concepts in politics. He anticipates later discourse by S.P. Huntington, Bo Stråth, and George Schöpflin, on "the identity-giving other."
} 
den as such might lack a goal except for the trivial but crucial ones of welfare and stability. John F. Kennedy's old imperative "Ask what you can do for your country" would sound odd to modern Swedish ears. But there are no major divides. We don't even have much tension between generations, since there is a general consensus that the generations that once built our welfare deserve their fair share of wealth, health service, and so forth. ${ }^{34}$

Real, existing, Swedish civil society is historically linked to nationbuilding, in odd contrast to the self-image in Sweden in the post-Second World War era.

It should also be noted that Sweden is a country "in the centre of the periphery," with a deficit of Enlightenment, yet quite a lot of Enlightenment reason in the formative years of social engineering (1930-1960), and with "rationalising intellectuals" in close conjunction with the political power. ${ }^{35}$ The Myrdals are again very good examples, as both of them had dual careers and became members of the Swedish government.

It would be misleading to conclude from previous reflections that the Swedish way is the "constructive" and responsible one, while the Polish model of civil society is anarchic and irresponsible. The models serve different purposes and are products of the historical determinants in their respective political cultures. The Swedes, like the Germans, have "never chopped off a king's head" and have had no real revolution since 1434 (1809 was a bourgeois coup d'etat and Gustaf Vasa's war of independence in the early 1520 s was a rather complex story with several conflicting interests involved and with Swedes on both sides). However, the Swedish model of civil society is evidently instrumental in promoting the infrastructure that made "Sweden, Inc." a historical success story.

On the eve of post-Westphalian Europe it might be noted that the Polish way was also extremely successful in eroding the legitimacy of a dysfunctional regime. Evidently it offers no optimal prescription for "beyond" or "towards the future," as Solidarity's charismatic leader Lech Wałęsa clearly saw early on. Yet both models answer the core intention of civil society, namely self-organisation (Kocka et al. 2001).

\footnotetext{
${ }^{34}$ This is, however, a problem area, where a lot of hardship is to be expected "around the corner," and which can only be solved on the pan-European level. Stein Ringen has done work on this. In Sweden the pension reform of the late 1950s (ATP) was regarded as the "flag-ship" of the modern welfare state, but simply had to be realigned, since it was not sustainable. According to a recent prognosis we have to work until age 78 or so in order to make ends meet. The system was not designed as an insurance system but as a redistribution system (between generations) and the new crisis in the population question is increasingly hurting, even if reproduction rates are higher in Sweden than in, for instance, Germany.

${ }^{35}$ Ron Eyerman's concept (1985).
} 


\section{/// Concluding Remarks}

What should be done, research-wise, and what can we learn? The latter question I leave to others - it depends on perspective and interest - but I would suggest that, for better or worse, long-term historical factors can be instructive. And that to understand Swedish exceptionalism, in the conceptual history of civil society as well as in real, existing civil society, further research needs to be done on främjandesällskap (promoting associations), social movements, and collective memory. ${ }^{36}$ Studies of early social-insurance initiatives, forestry cooperation, and electrification in the countryside might be particularly rewarding. This is a reasonable forecast, not an established fact. To a large extent, such a study might be a matter of scrutinising old substance from new vantage points. Considerable historical research may already have been done, for instance, on "promoting associations" between the private and the public. Re-conceptualised interpretive schemes or even theories might contribute to the formation of cumulative - perhaps even testable - knowledge. One might also speculate that combining research from history departments and the Kungliga Tekniska Högskolan, the technical university in Stockholm, might prove seminal, by throwing light upon civil society and infrastructure development (see Eliaeson \& Lödén 2002).

There are anomalies. Swedish religious non-conformists functioned more like the Poles, in effect contributing to an associational culture that facilitated the breakthrough to modern mass democracy. This followed a couple of decades of bad atmosphere in the country, with uneasiness over the new organisation of a conscript army in a Swedish Obrigkeitsstaat; the result was mass emigration to the USA, the largest people's movement in Swedish history. "One man, one rifle, one vote" was a slogan in the democratisation process leading up to the 1907-1909 compromise. The conservative paternalistic rule in Sweden was not in lockstep with the demands of modern mass democracy and the period between, say, 1880 and 1909 was characterised more by class conflict and stalemate than consensus and cooperation. Although there is a clear "merger" in Swedish political culture between Gemeinschaft and Gesellschaft, to employ Tönnies's terminology, this does not preclude the fact that the great transformation to industrialised mass society in Sweden also had its "bottlenecks." It appears, however, to have been a relatively smooth process, with two new elites in politics and

${ }^{36}$ The term "collective memory" creates some methodological problems. Eva Österberg's work is important for the understanding of its deep roots. 
the economy soon learning to cooperate in a simultaneous, intertwined process of constitutionalism and democratisation - which also explains the relative absence of crucial distinctions in Swedish political life between the Rechtsstaat, constitutional order, and democracy.

Of course, the labour movement was also momentous, although in comparison to Poland the political and trade union branches behaved early on as if they had read Mancur Olson Jr. before his main works were written. Mancur Olson in fact refers to Sweden as a deviant case in regard to the fiscal stress caused by special interests, which is lower than in other countries. The main and dominant Swedish labour union, the Landsorganisationen (LO) felt a responsibility for society as a whole, and behaved accordingly. When the large labour unions shifted to imposing their programme through legislation in the 1970s the cooperative spirit vanished and the Swedish model of consensus was replaced by so-called block politics and ideological confrontation. This has changed again, but that is an altogether different story. ${ }^{37}$

A brief summary might state that the neoliberals won the conceptual battle but not the related debate on the optimal relation between the state, the market, and civil society; rather the neoliberals have merely somewhat altered Sweden's state-centred understanding of society, which has very deep roots and displays a peculiar mixture of top-down and bottom-up features, of obedience and self-reliance.

Some limitations of the longue durée in history should, however, be mentioned. The perspective is telling and there is a deficit in our awareness of it, especially in Sweden, less so in Central Europe (Mitteleuropa). But it doesn't really exhaust the search for explanations and there are some obvious methodological problems. Sudden shifts such as die Wende in 1989 make the longue durée view and its lingering strength visible, but it cannot really be said that the view explains why "1989" happened precisely in 1989. We need to supplement explanations by the dull, idiographic, "jurisprudence" approach: "What led up to this event?" Pure long-term historical Entäusserungen doesn't easily live up to the Popperian criteria of testability (falsificationism).

The focus on the longue durée in the Swedish case might bring with it a harmonising or idyllic bias. However, although the consensual element is

\footnotetext{
${ }^{37}$ The so-called wage earners' funds being the most famous example, but it also applies to several very rapid (according to their critics) work-life reforms in the 1970s, probably explaining the shift in government in 1976. The wage-earners' funds were - in effect - inspired by previous theories of so-called functional socialism (Gunnar Adler-Karlsson), building upon legal positivist ideas formulated by Hägerström and advocated by Vilhelm Lundstedt.
} 
important and the sense of belonging to the Volksheim is genuine, it nevertheless appears reasonable to suggest that Swedish nation-building is also shaped by violence and war, in combination with taxation and national Bible translation. ${ }^{38}$

The Swedish model or experience is a success story - but not an export commodity. This does not preclude that it may contain useful elements from which to learn.

Interest in Swedish social history may be explained by the fact that several states in the post-Soviet space actually had a Stunde Null, when a fresh start from scratch seemed possible. It was thus perhaps tempting to try to apply the Swedish model - or some shining parts from its tool-shed. We can learn from history, but Swedish history, with all its particular formative factors, can not be repeated.

Bibliography:

/// Alexander J., ed. 1998. Real Civil Societies: Dilemmas of Institutionalization, Sage.

/// Andersson I., Weibull J. 1988. Swedish History in Brief, Swedish Institute.

/// Berggren H., Trägårdh L. 2014 [2006]. Är svensken människa? Gemenskap och oberoende i det moderna Sverige [Are Swedes Human Beings?], Norstedts.

/// Björk R. 1996. "Social Change, Scholarship, and Gunnar Myrdal: Reflections on the 1920s," [in:] Societies Made Up of History: Essays in Historiography, Intellectual History, Professionalisation, Historical Social Theory \& Protoindustrialisation - Festshrift to Rolf Torstendabl, ed. R. Björk, K. Molin, Akademitryck AB, pp. 87-110.

/// Britten Austin P. 1968. On Being Swedish: Reflections towards a Better Understanding of the Swedish Character, University of Miami Press.

/// Broberg G., Roll-Hansen N., eds. 1997. Eugenics and the Welfare State: Sterilization Policy in Norway, Sweden, Denmark, and Finland, Michigan State University Press.

38 The Uppsala historian Jan Lindegren elaborated on this in his inaugural lecture a few years ago. See also Lindegren 1985. In fact, Sweden was a prototype for Prussia, both militarily and in regard to rational bureaucracy in general. 
/// Chambers S., Kymlicka W., eds. 2002. Alternative Conceptions of Civil Society, Princeton University Press.

/// Childs M. 1936. Sweden: The Middle Way, Yale University Press.

/// Cochrane A., Clarke J., Gewirtz S., eds. 2001. Comparing Welfare States, $2^{\text {nd }}$ ed., Sage.

/// Cohen J., Arato A. 1994. Civil Society and Political Theory, MIT Press.

/// Dahl G. 1994. "The Swedish Model and the Conservative Revolution: Response to von Kreitor," TELOS, vol. 100, pp. 134-142.

/// Eliaeson S. 2000. "Axel Hägerström and Modern Social Thought," NORDEUROPAforum, vol. 1, pp. 19-30.

/// Eliaeson S. 2006a. "Gunnar Myrdal as a Weberian Public Intellectual," [in:] Das Faszinosum Max Weber: Die Geschichte seiner Geltung, eds. K.-L. Ay, K. Borchardt, Das Faszinosum Max Weber. Die Geschichte seiner Geltung, Universitätsverlag Konstanz, pp. 283-300.

/// Eliaeson S., ed. 2006b. Building Democracy and Civil Society East of the Elbe: Essays in Honour of Edmund Mokrzycki, Routledge.

/// Eliaeson S. 2008. "Gunnar Myrdal's Failure as Sweden's 'Grumpy Old Man': Rereading Hur Styrs Landet? Del 1. (How Is the Country Ruled? Part 1)," [in:] Academics as Public Intellectuals, eds. S. Eliaeson, R. Kalleberg, Cambridge Scholars Publishing, pp. 131-152.

/// Eliaeson S., Lödén H., eds. 2002. Nordisk Säkerhetspolitik inför Nya Utmaningar, Carlssons.

/// Eriksson B. 1988. Sambällsvetenskapens uppkomst [The Birth of Social Science], Hallgren \& Fallgren.

/// Eriksson B. 1993. "The First Formulation of Sociology: A Discursive Innovation of the $18^{\text {th }}$ Century," Archives Européennes de Sociologie, vol. 34(2), pp. 251-276.

/// Esping-Andersen G. 1990. Three Worlds of Welfare Capitalism, Polity Press.

/// Eyerman R. 1985. "Rationalizing Intellectuals," Theory and Society, vol. 14, pp. $77-108$.

/// Ferguson A. 2004 [1767]. An Essay on the History of Civil Society, Kessinger. 
/// Flora P., ed. 1986. Growth to Limits: The West European Welfare States since World War II, 5 vols, Walter de Gruyter.

/// Fromm E. 1941. Escape from Freedom, Farrar \& Reinhart.

/// Fukuyama F. 1995. Trust: The Social Virtues and the Creation of Prosperity, Free Press.

/// Gawin D., Gliński P., eds. 2006. Civil Society in the Making, IFiS Publishers.

/// Geremek B. 1991. "Die Civil Society gegen den Kommunismus: Polens Botschaft," [in:] Europa und die Civil Society, ed. K. Michalski, Klett-Cotta, pp. 264-273.

/// Greenfeld L. 1993. Nationalism: Five Roads to Modernity, Harvard University Press.

/// Götz N. 2001. Ungleiche Geschwister: Die Konstruktion von nationalsozialistischer Volkesgemeinschaft und schwedischem Volksheim, Nomos.

/// Hallenberg M. 2001. Kungen, Fogdarna och Riket: lokalförvaltning och statsbyggande under tidig Medeltid, Brutus Östlings bokförlag Symposium.

/// Hasselberg Y. 1998. Den sociala ekonomin. Familjen Clason och Furudal's bruk 1804-1856 [The Embedded Economy: The Clason Family and Furudal Ironworks 1804-1856], Uppsala Universitet.

/// Huntford R. 1972. The New Totalitarians, Allen Lane.

/// Johansson A.W., ed. 2001. Vad är Sverige? [What Is Sweden?], Prisma.

/// Kaelble H. 2006. "Civil Society: The Concept and the European Level," [in:] Building Democracy and Civil Society East of the Elbe: Essays in Honour of Edmund Mokrzycki, ed. S. Eliaeson, Routledge, pp. 360-365.

/// Kettunen P., Eskola H., eds. 1997. Models, Modernity and the Myrdals, The Renvall Institute for Area and Cultural Studies.

/// Kirby D. 1990. Northern Europe in the Early Modern Period: The Baltic World 1492-1772, Longman.

/// Kocka J. 1997. "The Difficult Rise of a Civil Society: Societal History of Modern Germany," [in:] German History since 1800, ed. M. Fulbrook, Arnold, pp. 493-511. 
/// Kocka J., Nolte P., Randeria S., Reichardt S. 2001. "Neues über Zivilgesellschaft aus historisch-sozialwissenschaftlichem Blickwinkel," WZB Discussion Paper, No. P 01-801.

/// Kohn M.L. 2003. Radical Space: Building the House of the People, Cornell University Press.

/// Kornhauser W. 1959. The Politics of Mass Society, Free Press.

/// Kreitor N.-K. von. 1994a. "The 'Conservative Revolution' in Sweden," TELOS, vol. 98-99, pp. 249-254.

/// Kreitor N.-K. von. 1994b. “The Political Idea of the People's Home: Reply to Goran Dahl," TELOS, vol. 100, pp. 143-156.

/// Lane R.E. 1972. Political Man, Free Press.

/// Lane J.-E., ed. 1990. Understanding the Swedish Model, Frank Cass. [Most contributions also available in: West European Politics, vol. 14(3), 1991.]

/// Lindblom C. 1977. Politics and Markets: The World's Political Economic Systems, Basic Books.

/// Lindegren J. 1985. “The Swedish 'Military State,' 1560-1720,” Scandinavian Journal of History, vol. 10(4), pp. 305-336.

/// Lönnroth E. 1934. Sverige och Kalmarunionen 1397-1457. [Doctoral thesis from University of Gothenburg.]

/// Lyon E.S. 2001. "Education for Modernity: The Impact of American Social Science on Alva and Gunnar Myrdal and the 'Swedish Model' of School Reform," International Journal of Politics, Culture and Society, vol. 14(3), pp. 513-537.

/// Metcalf M. 1987. "Parliamentary Sovereignty and Royal Reaction, 1719-1809," [in:] The Riksdag: A History of the Swedish Parliament, ed. M.F. Metcalf, Bank of Sweden Tercentenary Foundation, pp. 109-164.

/// Michalski K., ed. 1991. Europa und die Civil Society, Klett-Cotta.

/// Myrdal G. 1982. Hur styrs Landet? Del I [How Is The Country Governed, Part I], Rabén \& Sjögren.

/// Myrdal G. 2005. The Essential Gunnar Myrdal, eds. Ö. Appelqvist, S. Andersson, The New Press. [Selections from Vägvisare, Norstedts, 1998.] 
/// Offe C. 2004. Selbstbetrachtung aus der Ferne. Tocqueville, Weber und Adorno in den Vereinigten Staaten, Suhrkamp.

/// Olson Jr M. 1965. The Logic of Collective Action: Public Goods and the Theory of Groups, Harvard University Press.

/// Olson Jr M. 1982. The Rise and Decline of Nations, Yale University Press.

/// Olsson S.E. 1990. Social Policy and Welfare State in Sweden, Arkiv. [ $3^{\text {rd }}$ enlarged ed. under the name Sven Hort, 2 vols, 2014.]

/// Österberg E. 1991. Mentalities and Other Realities: Essays in Medieval and Early Modern Scandinavian History, Lund Studies in International History.

/// Petersson O. 1991. "Democracy and Power in Sweden," Scandinavian Political Studies, vol. 14(2), pp. 173-191.

/// Popenoe D. 1991. "Family Decline in the Swedish Welfare State," Public Interest, vol. 102, pp. 65-77.

/// Putnam R. 1993 Making Democracy Work: Civic Traditions in Modern Italy, Princeton University Press.

/// Putnam R. 2000. Bowling Alone, Simon \& Schuster.

/// Ringen S. 2005. Citizens, Families and Reform, $2^{\text {nd }}$ ed., Transaction Publishers.

/// Roberts M. 1986. The Age of Liberty: Sweden 1719-1772, Cambridge University Press.

/// Rothstein B. 1998. Just Institutions Matter: The Moral and Political Logic of the Universal Welfare State, Cambridge University Press.

/// Sandel M. Democracy's Discontent, Belknap.

/// Schmidt H. 2004. "Erweitern? Erst braucht Europa einen Kern," Die Zeit, no. 39, 16.09.2004, p. 23.

/// Shils E. 1991. "Was ist eine Civil Society?," [in:] Europa und die Civil Society, ed. K. Michalski, Klett-Cotta, pp. 13-51.

/// Tenbruck F.H. 1987. "Max Weber and Eduard Meyer," [in:] Max Weber and his Contemporaries, eds. W.J. Mommsen, J. Osterhammel, Unwin Hyman, pp. 234-267. 
/// Titmuss R. 1962. Income Distribution and Social Change: A Study in Criticism, Allen \& Unwin.

/// Trägårdh L. 1999. "Det civila samhället som analytiskt begrepp och politisk slogan,” Civilsambället, vol. 84, pp. 13-53.

/// Turner S. 2006. "Was 'Real Existing Socialism' Merely a Premature Form of Rule by Experts?," [in:] Building Democracy and Civil Society East of the Elbe: Essays in Honour of Edmund Mokrrycki, ed. S. Eliaeson, Routledge, pp. 248-261.

/// Vasara-Hammare N. 2002. "Sametinget i Sverige - parlament eller myndighet?" [The Sametinget in Sweden - Parliament or State Agency?], Statsvetenskaplig Tidskrift, vol. 105(2), pp. 158-165.

/// Weber M. 1906. “'Kirchen' und 'Sekten' in Nordamerika," Christliche Welt, vol. 20(24), pp. 558-562; vol. 20(25), pp. 577-583.

/// Wittrock B. 2004. "The Making of Sweden," Thesis Eleven, vol. 77, pp. 45-63.

/// Wolfe A. 1989. Whose Keeper? Social Science and Moral Obligation, University of California Press.

/// Zetterberg H. 1995. "Civila samhället, demokratin och välfärdsstaten” [Civil Society, Democracy, and the Welfare State], [in:] Civil sambälle kontra offentlig sector, ed. L. Trägårdh, SNS Förlag, pp. 62-93.

\section{/// Abstract}

Social science is a battlefield for the formation of concepts. The Swedish case is particular. "Civil society" re-entered the scene as a neoliberal and social-conservative reaction against the social-democratic ideology of the "strong state," in which the state and society were conceived to be almost synonymous.

The Swedish revival of an old concept is in obvious contrast with the concept's reception east of the Elbe in recent decades, where "civil society" has often been used as a label for grass roots social movements, which are independent of the state and the nomenklatura, in malfunctioning regimes with low legitimacy and poor output. This idea is lacking in the Swedish case, where we find a characteristic merger between the "top-down" 
and "bottom-up" perspectives. "Real, existing" civil society in Sweden has a long history. Self-organised initiatives sought support from the state and often received it - in some cases creating institutions that grew into state agencies. Forestry, electrification, and early social insurance provide examples of the interplay between the state, the market, and society.

Swedish civil society has deep roots in history, going back at least to late medieval days. Civil society was a formative element in the design of the relatively successful "Swedish model" through social engineering and piecemeal reforms during the period from the 1930s to the late 1960s.

Keywords:

civility, civil society, long duration in history, modernity, path dependency, 'Titmuss' triad, trust, Myrdal Gunnar, Oxenstierna Axel

/// Sven Eliaeson - Ph.D. at Uppsala University (1982), docent at Stockholm University (1996), frequent visiting professor in sociology at CSS/GSSR at IFiS PAN in Warsaw, senior research fellow at IRES (Institute for Russian and Eurasian Studies) in Uppsala, and currently senior research fellow at PIASt in Warsaw. He has written numerous works, including on Max Weber, Axel Hägerström, and Gunnar Myrdal, and has had many research sojourns at American and German universities.

Email: sven.eliaeson@ires.uu.se 
